Research Report No. 21/2011

\title{
Defining the Space of Transnational Law: Legal Theory, Global Governance and Legal Pluralism
}

Peer Zumbansen

Osgoode Hall Law School of York University, PZumbansen@osgoode.yorku.ca

Follow this and additional works at: http:// digitalcommons.osgoode.yorku.ca/clpe

\section{Recommended Citation}

Zumbansen, Peer, "Defining the Space of Transnational Law: Legal Theory, Global Governance and Legal Pluralism" (2011). Comparative Research in Law \& Political Economy. Research Paper No. 21/2011.

http://digitalcommons.osgoode.yorku.ca/clpe/59 


\section{OSGOODE}

OSGOODE HALL LAW SCHOOL

YOR K U N I VERSITY

\section{OSGOODE HALL LAW SCHOOL}

Comparative Research in Law \& Political Economy

RESEARCH PAPER SERIES

Research Paper No. 21/2011

Defining the Space of Transnational Law: Legal Theory, Global Governance \& Legal Pluralism

Peer Zumbansen

\section{Editors:}

Peer Zumbansen (Osgoode Hall Law School, Toronto, Director, Comparative Research in Law and Political Economy) John W. Cioffi (University of California at Riverside) Lisa Philipps (Osgoode Hall Law School, Professor of Law)

Leeanne Footman (Osgoode Hall Law School, Toronto, Production Editor) 
Osgoode CLPE Research Paper 21/2011

Vol. 07 No. 05 (2011)

Peer Zumbansen

\title{
Defining the Space of Transnational Law: Legal Theory, Global Governance \& Legal Pluralism
}

\begin{abstract}
Transnational law, since its iteration by Philip Jessup in the 1950s, has inspired a league of scholars to investigate into the scope, doctrine, sources and practice of bordercrossing legal regulation. This paper reviews much of this preceding scholarly work and attempts to contextualize it in debates around global governance and global constitutionalism. These debates are no longer confined to international lawyers or political scientists. Together with anthropologists, sociologists, geographers and legal philosophers and legal theorists, these scholars have been significantly widening the scope of their investigation. The current, multi- and interdisciplinary research into the prospects of political sovereignty, democratic governance and legal regulation on a global scale suggests a further continuation of such intellectual bricolage and collaboration. The here presented paper builds on a larger research project into the methodology of transnational law and suggests that we ought to revisit legal sociological insights into the emergence of legal pluralism to make sense of today's co-evolution of 'formal' and 'informal', 'public' and 'private' laws - and social norms.
\end{abstract}

Key words: Transnational Law, Global Governance, Legal Pluralism, Global Constitutionalism

Jel Classification: K 10, K 33

- This paper is based on the Keynote Address delivered at the occasion of the $20^{\text {th }}$ Anniversary Celebration of the University of Iowa's College of Law's TRANSNATIONAL LAW \& CONTEMPORARY PRoBlems in March 2011. I am very grateful to the Journal editors and to Dean Agrawal and Professor Somek at the College of Law for the honoring invitation. The article draws in small part from and builds on my Transnational Legal Pluralism in 1 TrANSNATIONAL LEGAL THEORY 141 (2010), http://ssrn.com/abstract=1542907.

${ }^{*}$ LL.B., Ph.D. (Law), Habilitation (Frankfurt); Licence en droit (Paris); LL.M. (Harvard). Professor of Law, Canada Research Chair, Osgoode Hall Law School. Summer 2011, Fellow, Hanse Institute of Advanced Study (www.h-w-k.de). Pzumbansen@osgoode.yorku.ca. 


\section{A. InTRODUCTION}

Legal inquiries into the future of law in an era of globalization are regularly confronted with accounts of law's alleged weakness to effectively extend beyond national, jurisdictional boundaries. At the same time, lawyers are by far not the only scholars reflecting on the regulatory challenges today often summarized under the heading of 'global governance'. An investigation into the nature and scope of legal regulation in this context is unavoidably exposed to questions of origin and function on the one hand and to questions of relations, compatibility and interdisciplinarity on the other. In this often polemic and heated discourse of disciplines and narratives, an effort to reconstruct a discipline's approach and methodology offers insights into the trajectories and characteristics of a particular discipline's 'take' on the problems which are at stake in a fast evolving highly asymmetric global arena.

With these considerations in mind, the following article takes seriously the concerns among international lawyers about 'legal fragmentation'1 if only to contrast and to compare them with the evolution of legal orders on the state level. Such mirroring offers a respite in what has otherwise too quickly been offered as a swan song about law's fading light and impact under the duress of globalization. ${ }^{2}$ Drawing out the analogies between legal sociological insights from the late $19^{\text {th }}$ and early $20^{\text {th }}$ century into pluralistic legal orders and the lament about the law's loss of 'unity' in the global context, we can take a better look at the ambivalent nature of law itself. What emerges through this lens is that our analytical focus ought not to be how law performs in the context of globalization, but how we are in fact theorizing the relation between law and society. In other words, the advent of globalization prompts an investigation into the theory/ies of society which inform(s) our and competing - understandings of law.

\footnotetext{
1 See the insightful and critical analysis by Martti Koskenniemi/Paivi Leino, Fragmentation of International Law? Postmodern Anxieties, 15 LEIDEn JoURnAL OF InTERnATIONAL LAW 553 (2002).

${ }^{2}$ For a rejection of the idea that law is a victim to globalization, see, from the perspective of law, Alfred C. Aman Jr., The Limits of Globalization and the Future of Administrative Law: From Government to Governance, 8 INDIANA JoURNAL OF GLOBAL LEGAL STUDIES 379 (2001), and, from sociology, Saskia Sassen, Globalization and Its Discontents. Essays on the New Mobility of People and Money (1998).
} 
A powerful illustration of this nexus is provided by the current debate on 'global constitutionalism' and the alleged or complementary 'constitutionalization' of international law. ${ }^{3}$ Running through the majority of analyses offered in this context is the contention that the absence of a 'world government' radicalizes the governance dilemma facing modern societies and in turn invites reflections on the way in which the improvement of participatory elements can strengthen the democratic foundations of global governance institutions on the one hand ${ }^{4}$, while the gradual acceptance of core human rights values may eventually foster the emergence of a global set of values, on the other. ${ }^{5}$ Such contentions, however, occur in surprising isolation from legal theory and governance discourses which have long been pursued within the framework of the nation state. The separate tracks of inquiry in this case, one focusing on the future of law and law's fragmentation in an era of globalization, and the other one concerned with the transformation of law in the context of radically transformed statehood ${ }^{6}$, prevent us from taking a closer look at the ways in which law has been changing over time. Certainly, scholars in law, political science or sociology have long been interested in the connections between the evolution of state institutions and the development of a global political economy. ${ }^{7}$ But, such inquiries focusing on the entanglements between political and legal institutions on the one hand and on the myriad forms of 'state-market' relations from a

\footnotetext{
${ }^{3}$ See eg Christian Walter, Constitutionalizing (Inter)national Governance - Possibilities and Limits to the Development of an Inernational Constitutional Law, 44 GERMAN YEARBOOK OF INTERNATIONAL LAW 170 (2001), Anne Peters, The Merits of Global Constitutionalism, 16 InDIANA JouRnal OF GLOBAL LEGAL STUDies 397 (2009). Compare with Antje Wiener, Global Constitutionalism: Mapping an Emerging Field. Background paper for the Conference: Constitutionalism in a New Key?, Berlin 28-29 January 2011 (http://cosmopolis.wzb.eu/content/program/conkey_Wiener_Mapping-Field.pdf) (2011)

${ }^{4}$ See eg Nico Krisch/Benedict Kingsbury/Richard B. Stewart, The Emergence of Global Administrative Law, 68 LAW AND CONTEMPORARY PROBLEMS 15 (2005). For a discussion, see Ladeur - in this volume.

${ }^{5}$ For a critical discussion, see UpendRA BAXI, The DEATH of HumAn Rights, 2ND ED. (2005).

${ }^{6} \mathrm{~A}$ case in point is the transformation of the 'welfare state' - see eg Paul Pierson, The New Politics of the Welfare State, 48 WORLD POLITICS 143 (1996).

${ }^{7}$ See Philip Manow, Welfare State Building and Coordinated Capitalism in Japan and Germany, in: THE ORIGINS OF NonliBeral CAPITALISM 94 (Streeck/Yamamura Ed. 2001), Fritz W. Scharpf, The viability of advanced welfare states in the international economy: vulnerabilities and options, 7 JOURNAL OF EUROPEAN PUBLIC POLICY 190 (2000).
} 
political economy perspective ${ }^{8}$, on the other, are too rarely included in current contentions of global 'legal fragmentation'. As a result, the challenges of global governance are addressed with too little connection to ongoing attempts to trace their origins in or connections with prior 'governance' discourses through which modern societies have long been described. In the present article, I coin the perspective between 'national' and 'global' governance challenges 'transnational' to offer a bridge between these separately pursued research agendas. Going beyond early work in international legal theory ${ }^{9}$ and partly drawing on the insights from 'transnational' commercial law ${ }^{10}$, we can begin to understand 'transnational law', above all, as a methodological approach and less as a distinctly demarcated legal 'field' such as, say, contract law, or administrative law. Transnational law, from the here taken perspective ${ }^{11}$, emerges foremost as a methodological lens through which we can study the particular transformation of legal institutions in the context of an evolving complex society. As we relativize contentions of society being the 'other' side of the 'state'12, which are running deep within the continental legal imagination, we begin to recognize the necessity of 'defining' society as such rather than merely assuming it as a given background, against which we may freely theorize about the 'future of law'. ${ }^{13}$

\footnotetext{
${ }^{8}$ See eg K. Polanyi, The Great Transformation. The Political and Economic Origins of our Time (1944); Paul Pierson, Politics in Time. History, Institutions, and Social Analysis (2004); Harry W. Arthurs, Governance After the Washington Consensus: The Public Domain, the State and the Microphysics of Power in Contrasting Economies, MAN \& DEVELOPMENT 85 (2002).

${ }^{9}$ See Philip C. Jessup, Transnational Law (1956), and Harold J. Berman, World Law, 18 FordHAm InTERnATIONAL LAW JOURNAL 1617 (1995).

10 Berthold Goldman, Arbitrage International et droit commun des nations, REvUE DE L'ARBITRAGE 115 (1956), Clive M. Schmitthoff, International Business Law: A New Law Merchant, 2 CuRrent LAW AND Social ProblemS 129 (1961), Roy Goode, Usage and Its Reception in Transnational Commercial Law, 46 INTERNATIONAL AND COMPARATIVE LAW QuARTERLY 1 (1997), Ross Cranston, Theorizing Transnational Commercial Law, 42 TeXAS INTERNATIONAL LAW JOURNAL 597 (2007)

${ }^{11}$ For a more extensive discussion, see Peer Zumbansen, Transnational Law, in: EnCYCLOPEDIA of Comparative LAW 738 (Smits Ed. 2006), and Peer Zumbansen, Neither 'Public' nor 'Private', 'National' nor 'International': Transnational Corporate Governance from a Legal Pluralist Perspective, 38 JOURNAL OF LAW \& SOCIETY 50 (2011).

12 For a powerful discussion of this assumption, see JÜrgen Habermas, The Postnational Constellation (2001).

13 This is forcefully argued by THOMAs VeSTING, ReChTSTHEORIE (2007).
} 
The sociology of law and, more specifically, the work on 'legal pluralism', as promulgated very early by scholars such as Eugen Ehrlich ${ }^{14}$ or Georges Gurvitch ${ }^{15}$ and later built upon in work by Sally Falk Moore ${ }^{16}$, John Griffiths ${ }^{17}$, Sally Merry ${ }^{18}$ and Gunther Teubner ${ }^{19}$, provides a powerful pathway towards a transnational legal methodology, which traces the emergence of legal regulatory institutions in the context of an evolving society - on the 'national' and the 'international' level. Focusing on the co-existence and competition between hard and soft, official and inofficial, public and private norms, the here proposed approach - labelled 'transnational legal pluralism' - suggests to study law from a methodological angle in the context of evolving theoretizations of societal ordering rather than as a contained discipline. Central to this undertaking is a shift in perspective, which leads to a focus on actors, norms and processes as building blocks of a methodology of transnational law. ${ }^{20}$

This approach suggests a relativization of a number of assumptions commonly associated with law. One is its territorial connection with a politically institutionalized system of rule creation, implementation and adjudication, which in Europe has for a relatively long time been framed as the state-law nexus. From a transnational perspective, this nexus becomes questionable, as around the world, but also in Europe itself, the legal sociological lens reveals an impressive array of non-state originating norms that have long been binding

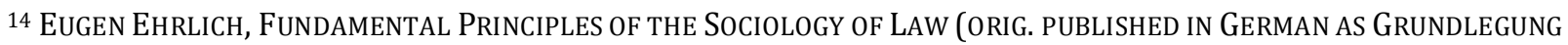
DER SOZIOLOGIE DES RECHTS, 1913) (1962)

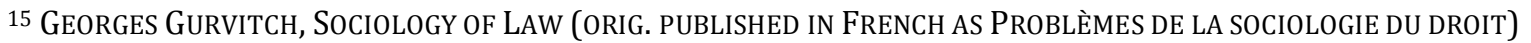
(1947)

${ }^{16}$ Sally Falk Moore, Law and Social Change: the semi-autonomous field as an appropriate subject of study, 7 LAW \& Society Review 719 (1973); Sally Falk Moore, Law as Process (1978)

${ }^{17}$ John Griffiths, What is Legal Pluralism?, 24 Journal of LEgal PluRalism and Unofficial LaW 1 (1986)

${ }^{18}$ Sally Engle Merry, Legal Pluralism, 22 Law \& SocieTy Review 869 (1988); Sally Engle Merry, New Legal Realism and the Ethnography of Transnational Law, 31 LAW \& SOCIAL INQUIRY 975 (2006)

${ }^{19}$ Gunther Teubner, After Legal Instrumentalism? Strategic Models of Post-regulatory Law, in: DiLEMmaS of LAW In THE WelFare STATE 299 (Teubner Ed. 1986); Gunther Teubner, The Two Faces of Janus: Rethinking Legal Pluralism, 13 CARdozo LaW Review 1443 (1992)

${ }^{20}$ For an application of this approach for a law school course, see ALFREd C. AMAN JR \& PEER Zumbansen, Transnational LaW: ACTORS, NoRms, Processes (Lexis-Nexis, 2012 - forthcoming).
} 
human and organizational behaviour. ${ }^{21}$ This observation has prompted sociologists to perceive of law primarily from a functional perspective, emphasizing its particular operation in the context of a differentiated modern society. ${ }^{22}$ From the vantage point of this theory, society is no longer validly represented as a sphere defined primarily in contrast from the state - rather, in a society 'without peak or centre' (Luhmann), law is but one of several societal forms of communication, unfolding according to its own rationality and by use of its own particular vocabulary ('code'). ${ }^{23}$

Even if one does not go so far as to represent law as nothing but a particular form of societal communication, the contention of a specific nexus between law and a (theory of) society in which law emerges and operates promises to render insights into the evolving forms of law, which appear much more adequate depictions of law than the ambivalent attempts to reconcile the assumption of a strong state-law nexus with the proliferation of numerous, non-state based rule generating processes and institutions.

Beyond the relativization of the law/non-law distinction, which is inherent to the legal sociological/legal pluralist approach to legal regulation, there is the other significant challenge arising out of the law-society approach taken here, namely the already mentioned relativization of a territorial grounding of law in a particular jurisdiction. As we study law in its societal context, the confines of society can no longer adequately be drawn with reference to specific states, nations or regions. Instead, society must be perceived as world society. ${ }^{24}$ Within world society, the study of law (and of regulatory governance more generally) refers to 'territory', 'jurisdiction' or the 'state' in order to appreciate specific, historically grown or politically constituted frameworks of legal evolution at a particular

\footnotetext{
${ }^{21}$ Harry W. ARthurs, Without the LaW: Administrative Justice and Legal Pluralism in Nineteenth Century ENGLAND (1988); EHRLICH, supra, note 14; for an insightful resumé, see Marc Galanter, Farther Along, 33 LAW \& SoCiETY REVIEW 1113 (1999), and Marc Galanter, In the Winter of our Discontent: Law, Anti-Law, and Social Science, ANNUAL REviEW of LAW \& SOCIAL SCIENCES 1 (2006).

22 Niklas Luhmann, A Sociological Theory of LaW (1985); Niklas Luhmann, Law as a Social System, 83 NORTHWESTERN UNIVERSITY LAW REVIEW 136 (1989); Niklas Luhmann, Operational closure and structural coupling: the differentiation of the legal system, 13 CARDOZo LAW REVIEW 1419 (1992)

${ }^{23}$ Niklas Luhmann, Political Theory in the Welfare State [1981, transl. By John Bednarz JR.] (1990)

${ }^{24}$ Niklas Luhmann, The World Society as a Social System, 8 InTERnATIONAL Journal OF GENERAL SySTEMS 131 (1982); see also John W. Meyer/John Boli/George M. Thomas/Francisco O. Ramirez, World Society and the Nation-State, 103 AmeriCAN Journal OF SOCIOLOGY 144 (1997).
} 
given time and in a particular space - no more and no less. The 'no less' deserves particular emphasis in the context of frequently made assertions of an allegedly de-territorialized ${ }^{25}$ or 'autonomous' legal order. ${ }^{26}$ From the here suggested methodological perspective, such assertions are of lesser interest with regard to their explanatory value as to their motives. In order to unpack the claims of an increasingly de-territorialized or, autonomous nature of regulatory governance it is necessary, on the one hand, to revisit the arguments, which are launched by some scholars who connect the claim of an 'exhaustion' of law and of the nation-state's regulatory power with an emphasis on 'social norms'. ${ }^{27}$ On the other hand, we need to study the arguments of scholars who describe transnational law as grounded in what they refer to as 'global' legal pluralism. ${ }^{28}$ As we will see in the following, both groups of scholars put a particular emphasis on the limits of traditional legal regulation and question the adequacy of the state-law nexus to capture the dynamics of regulatory governance today. But, a closer look at the arguments appears to reveal that the shared interest in a legal pluralist description of governance originates from different political standpoints. As regards the scholars who argue that the state is increasingly reaching its regulatory capacity, such arguments mainly seem driven by a rejection of so-called 'interventionist' state policy, reminiscent as such from the discussions around the U.S. Supreme Court's Lochner jurisprudence. ${ }^{29}$ By contrast, scholars in legal sociology and legal theory with a strong interest in questions of 'access to justice' and the problem of the legal system's closedness to wide sections of society mobilized a limits-of-law critique from an

\footnotetext{
${ }^{25}$ See Ralf Michaels, Territorial Jurisdiction after Territoriality, in: GLOBALISATION AND JURISDICTION 105 (Slot/Bulterman Ed. 2004).

26 See eg Emmanuel GaILLARd, Legal Theory of International Arbitration (2010); see also Gunther Teubner, 'Global Bukowina': Legal Pluralism in the World Society, in: Global LAW Without A STATE 3 (Teubner Ed. 1997)

27 ERIC A. Posner, LAW AND Social Norms (2000)

28 Paul Schiff Berman, Global Legal Pluralism, 80 Southern CALIFornia LaW REview 1155 (2007); Paul Schiff Berman, The New Legal Pluralism, AnNuAl Review of LAW AND Social Sciences 225 (2009); Ralf Michaels, Global Legal Pluralism, Duke Public Law \& Legal Theory Research Paper No. 259 http://papers.ssrn.com/sol3/papers.cfm?abstract_id=1430395 (2009)

${ }^{29}$ Lochner v. New York, 198 U.S. 45 (1905); for an insightful history of the case's reception and legacy, see Sujit Choudhry, The Lochner Era and Comparative Constitutionalism, University of TORONTO FACULTY OF LAW, Public LaW and Legal Theory Research PAPER No. 02-22 (2002).
} 
opposed political perspective. ${ }^{30}$ This 'availability' of legal pluralist thinking to different, even juxtaposed political projects ${ }^{31}$ forms a crucial background to today's assertions of the nature and aspiration of law in a global context, given the evolving forms of regulatory institutions. ${ }^{32}$

On that basis, it becomes possible to read the currently dominant narrative of the autonomization of law or of an 'end of (state-based) law' in an era of globalization in a different light. Rather than describing the advent of globalization as an end-point of legal development, from a transnational perspective it becomes necessary to deconstruct the various law-state associations in order to gain a more adequate understanding of the evolution of law in relation and response to the development of what must be described as 'world society'. The currently lamented lack of democratic accountability, say, in international economic governance ${ }^{33}$, can then be perceived as a further development in a highly differentiated and de-territorialized society. The article thus rejects the attempts by lawyers to re-align transnational governance actors with traditional concepts of the state or of civil society and, instead, contrasts them with various advances in sociology and anthropology with regard to the evolution of 'social norms' and 'spaces' of governance and regulation. These perspectives, on the one hand, effectively challenge present attempts to conceptualize a hierarchically structure global legal order, while they question the association of legal rule creation with a territorially fixed place, on the other. As such, the here proposed concept of 'transnational legal pluralism' [TLP] goes beyond Philip Jessup's 1956 idea of 'transnational law', through which he sought to complement and challenge

\footnotetext{
${ }^{30}$ See eg Marc Galanter, Why the 'Haves' Come Out Ahead: Speculations on the Limits of Legal Change, 9 Law \& SOCIETY REVIEW 95 (1974); see the retrospective discussion by Orly Lobel, The Paradox of Extralegal Activism: Critical Legal Consciousness and Transformative Politics, 120 HARVARD LAW REvIEW 937 (2007).

${ }^{31}$ For more background, see Peer Zumbansen, Law After the Welfare State: Formalism, Functionalism and the Ironic Turn of Reflexive Law, 56 AMERICAN JOURNAL OF COMPARATIVE LAW 769 (2008).

32 See eg Adrienne Héritier/Dirk Lehmkuhl, The Shadow of Hierarchy and New Modes of Governance, 28 JouRnal OF Public Policy 1 (2008); Alec Stone Sweet, Constitutionalism, Legal Pluralism, and International Regimes, 16 Indiana Journal of Global LEGAl Studies 621 (2009); Christiana Ochoa, The Relationship of Participatory Democracy to Participatory Law Formation, 15 Indiana JouRnal OF GLOBAL LEGAL STUdies 5 (2008).

${ }^{33}$ David Schneiderman, Realising Rights in an Era of Economic Globalisation: Discourse Theory, Investor Rights, and Broad-Based Black Economic Empowerment, in: REDEFINING SOVEREIGNTY IN INTERNATIONAL ECONOMIC LAW 429 (Shan/Simons/Singh Ed. 2008); see also Alexander Somek, The argument from transnational effects II: Establishing transnational democracy, 16 EUROPEAN LAW JOURNAL 375 (2010).
} 
Public and Private International Law. TLP brings together insights from legal sociology and legal theory with research on global justice, ethics and regulatory governance to illustrate the transnational nature of law and regulation, always pushing against the various claims to legal unity and hierarchy made over time.

The article is structured as follows: The next section (B) revisits the legal pluralist insights into the tension between law and non-law. Against this background, the article will trace the emergence of border-crossing regulatory regimes as a challenge to state-oriented legal reasoning (C). It illustrates the parallels between the impasses of legal theorising about 'global' or 'transnational' governance with those that marked the evolution of law in the nation- state. Section D revisits the frequently asked question whether globalisation marks the end of law: attempting a negative answer ('law is dead - long live law!'), this section proposes to read the emergence of 'transnational law' not as the advent of a 'new' field similar to the way that, say, environmental law or internet law were considered 'new' only relatively recently. Instead, the central assumption is that transnational law constitutes a methodological shift in legal theory - an attempt to bridge the experience of legal pluralism in the nation state with that of the emerging transnational space. Section $\mathbf{E}$ pursues this argument and applies it to the initial paradox between law and non-law. Transnational law can now be understood as a lens through which to perceive the argumentative parallels between the impasses, roadblocks and 'impossibilities' of law that recur both 'inside' and 'outside' of the nation state. As the borders of the state are reconstructed as historically contingent reference points for the evolution of legal reasoning, transnational law becomes the legal theoretical reconstruction of law/non-law in the world society. The concluding section (F) sets out the framework of transnational legal pluralism. 


\section{B. The Anxieties of Global Governance and the Ambivalent Nature of Law}

Today, many regulatory areas can be understood as instantiations of transnational normcreation. Supply chains that tie regional and global markets together ${ }^{34}$, commercial $\operatorname{arbitration}^{35}$, food safety and food quality standardisation regimes ${ }^{36}$, internet governance ${ }^{37}$, but also environmental protection ${ }^{38}$, crime $^{39}$ and terrorism ${ }^{40}$ are key examples of fast expanding spaces of individual, organizational and regulatory activity that evolve with little regard for jurisdictional boundaries. Similarly, fields such as company,

\footnotetext{
${ }^{34}$ Francis Snyder, Global Economic Networks and Global Legal Pluralism, in: Transatlantic Regulatory Cooperation (http://cadmus.iue.it/dspace/bitstream/1814/151/1/law99_6.pdf)

(Bermann/Herdegen/Lindseth Ed. 2000); Francis Snyder, Economic Globalisation and the Law in the 21st Century, in: The Blackwell Companion to Law and Society 624 (Sarat Ed. 2004).

35 Clive M. Schmitthoff, The New Sources of the Law of International Trade, 15 International Social Science Journal 259 (1963); Filip De Ly, Lex Mercatoria (New Law Merchant): Globalisation and International SelfRegulation, in: Rules and Networks. The Legal Culture of Global Business Transactions 159

(Gessner/Appelbaum/Felstiner Ed. 2001).

${ }^{36}$ Patrycja Dabrowska, Risk, Precaution and the Internal Market: Who Won the Day in the Recent Monsanto Judgement of ECJ on GM foods, 5 German Law Journal 151 (2004); Dayna Nadine Scott, Nature/Culture Clash: The Transnational Trade in GMOs, Global Law Working Paper Series http://www.nyulawglobal.org/GLWP_0605.htm (2005); Antonia Eliason, Science versus Law in WTO Jurisprudence: The (Mis)Interpretation of the Scientific Process and the (In)sufficiency of Scientific Evidence in Ec-Biotech, $41 \mathrm{New}$ York University Journal of International Law \& Politics 341 (2009).
}

${ }^{37}$ David D. Clark, A Cloudy Crystal Ball: Visions of the Future, Plenary Presentation at 24th meeting of the Internet Engineering Task Force, Cambridge, Massachusetts, 13-17 July 1992

(http://ietf20.isoc.org/videos/future_ietf_92.pdf) (1992); Christoph Engel, The Role of Law in the Governance of the Internet, Preprints of the Max Planck Project Group Law of Common Goods 2002/13, Bonn, available at: http://www.mpp-rdg.mpg.de/pdf_dat/2002_13.pdf; Jack Goldsmith, The Internet, Conflicts of Regulation and International Harmonisation, in: Governance of Global Networks in the Light of Differing Local Values 197 (Engel/Keller Ed. 2000); Jochen von Bernstorff, The Structural Limitations of Network Governance: ICANN as a Case in Point, in: Transnational Governance and Constitutionalism 257 (Teubner/Joerges/Sand Ed. 2004).

38 Jutta Brunnée, Of Sense and Sensibility: Reflections on International Liability Regimes as Tools for Environmental Protection, 53 International and Comparative Law Quarterly 351 (2004); Oren Perez, Ecological Sensitivity and Global Legal Pluralism. Rethinking the Trade and Environment Conflict (2004); Russell Miller/Rebecca Bratspies (Ed.), Transboundary Harm: Lessons from the Trail Smelter Arbitration, 2006; Andrew P. Morriss/Roger E. Meiners, Borders and the Environment, 39 Environmental Law 141 (2009); see also John Conley/Cynthia Williams, Global Banks as Global Sustainability Regulators? The Equator Principles, 33 Law \& Policy forthcoming (2011)

39 Tomer Broude/Doron Teichman, Outsourcing and Insourcing Crime: The Political Economy of Globalized Criminal Activity, 62 Vanderbilt Law Review 795 (2009).

${ }^{40}$ Ulrich Beck, Living in the world risk society, 35 Economy and Society 329 (2006); Ulrich Beck, Critical Theory of World Risk Society: A Cosmopolitan Vision, 16 Constellations 3 (2009); Ulrich Beck, World at Risk [orig. German "Weltrisikogesellschaft" (Frankfurt: Suhrkamp); Ciaran Cronin, transl.] (2009). 
insolvency and even labour law that had long been understood as embedded in historically evolved political and regulatory economies ${ }^{41}$, today display a distinctly transnational character. ${ }^{42}$ Constituted through a complex overlapping of different national, international, public and private norm-creation processes, these fields underscore the conundrical nature of the proliferating global regulatory space: in response, state-based categorizations of normative hierarchy, separation of powers and unity of law ${ }^{43}$ fall short of grasping the nature of the evolving transnational normative order. ${ }^{44}$

It is easy to recognize a certain sense of urgency ${ }^{45}$ in the current search for appropriate labels, concepts and instruments for this regulatory space, for which lawyers have long been forming alliances with scholars in a wide range of social sciences including sociologists, political scientists, economists or geographers. Such interdisciplinary collaboration in practice and methodology is anything but new to law and legal theory building on early beginnings made by social scientists that emphasised the importance of

\footnotetext{
${ }^{41}$ See, eg: Sigurt Vitols, Varieties of Corporate Governance: Comparing Germany and the UK, in: Varieties of Capitalism. The Institutional Foundations of Comparative Advantage 337 (Hall/Soskice Ed. 2001), and Klaus J. Hopt, Common Principles of Corporate Governance in Europe?, in: Corporate Governance Regimes. Convergence and Diversity 175 (McCahery/Moerland/Raaijmakers/Renneborg Ed. 2002).

${ }^{42}$ Harry Arthurs/Claire Mummé, From Governance to Political Economy: Insights from a Study of Relations between Corporations and Workers, 45 Osgoode Hall Law Journal 439 (2007); Jennifer Gordon, Transnational Labor Citizenship, 80 Southern California Law Review 503 (2007); Peer Zumbansen, 'New Governance' in European Corporate Governance Regulation as Transnational Legal Pluralism, 15 European Law Journal 246 (2009); Horst Eidenmüller, Recht als Produkt, 64 Juristenzeitung [JZ] 641 (2009).

${ }^{43}$ For an inspiring discussion, see Klaus Günther, Legal Pluralism or uniform concept of law? 5 no foundations [NoFo] 5 (2008); Florian F. Hoffmann, In Quite a State: Trials and Tribulations of an Old Concept in New Times, in: Progress in International Law 263 (Miller/Bratspies Ed. 2008); William Twining, Globalisation and Legal Theory (2000).

${ }^{44}$ Oren Perez, Normative Creativity and Global Legal Pluralism: Reflections on the Democratic Critique of Transnational Law, 10 Indiana Journal of Global Legal Studies 25 (2003); Zumbansen (2006), supra, note 11; T. Alexander Aleinikoff, Transnational Spaces: Norms and Legitimacy, 33 Yale Journal of International Law 479 (2008); Alec Stone Sweet, Constitutionalism, Legal Pluralism, and International Regimes, 16 Indiana Journal of Global Legal Studies 621 (2009); Craig M. Scott, 'Transnational Law' as Proto-Concept: Three Conceptions, 10 German Law Journal 859 (2009).

${ }^{45}$ Rebecca Bratspies, Regulatory Trust, 51 Arizona Law Review 575 (2009); see the contributions to Edward Balleisen/David Moss (Ed.), Government and Markets: Toward a New Theory of Regulation, 2009.
} 
social facts and increasingly incorporated empirical findings ${ }^{46}$, the study of law has for the longest time been carried out in close proximity and in the constant shadow of social studies. ${ }^{47}$ The already alluded to legal sociological projects at the end of the $19^{\text {th }}$ and the beginning of the $20^{\text {th }}$ century can today be seen as eminent precursors for an only intensifying study into the institutional foundations of legal systems in a constellation marked by the erosion of boundaries between domestic legal orders and the continuing contestation of the normative-conceptual foundations of the Rule of Law, the welfare state and its ambiguous aftermath. ${ }^{48}$ The Legal Realist attack on formalism ${ }^{49}$, the post-War natural law/legal positivism debate ${ }^{50}$, the emergence of legal pluralism in the wake of postcolonialism ${ }^{51}$, the rise of 'law \& society' - both from the left ${ }^{52}$ and from the right ${ }^{53}$ - as well

\footnotetext{
${ }^{46}$ Adam Ferguson, An Essay on the History of Civil Society [1767] (1995); Emile Durkheim, The Division of Labor in Society [1893; transl. by W.D. Halls] (1984).

${ }^{47}$ Henry Sumner Maine, Ancient Law. Its connection with the early history of society, and its relation to modern ideas (1861); Ferdinand Tönnies, Community and Society [Gemeinschaft und Gesellschaft, orig. German 1887, transl. Ch. P. Loomis, Michigan State University Press, 1957] (1988); Max Weber, On Law in Economy and Society (transl. from the German Wirtschaft und Gesellschaft, 2nd ed., 1925, by E.Shils and M.Rheinstein, edited/annotated by M.Rheinstein) (1967).

48 David Trubek, Toward a Social Theory of Law: An Essay on the Study of Law and Development, 82 Yale Law Journal 1 (1972); Gunther Teubner (Ed.), Dilemmas of Law in the Welfare State, 1986; Zumbansen (2008), supra, note 31.

${ }^{49}$ See, eg: Oliver Wendell Jr. Holmes, The Path of the Law, 10 Harvard Law Review 457 (1897), and Felix Cohen, Transcendental Nonsense and the Functional Approach, 35 Columbia Law Review 809 (1935); Duncan Kennedy, The Rise and Fall of Classical Legal Thought (1975) (2006); a very worthwhile discussion and analysis with a stunning treatment of the literature is provided by Neil Duxbury, Patterns of American Jurisprudence (1995).

${ }^{50}$ HLA Hart, Positivism and the Separation of Law and Morals, 71 Harvard Law Review 593 (1958); Lon Fuller, Fidelity to Law - A Reply to Professor Hart, 71 Harvard Law Review 629 (1958); H.L.A. Hart, American Jurisprudence Through English Eyes: The Nightmare and the Noble Dream, 11 Georgia Law Review 969 (1977); Stanley L. Paulson, On the Background and Significance of Gustav Radbruch's Post-War Papers, 26 Oxford Journal of Legal Studies 17 (2006).

51 Moore (1973), supra, note 16; Boaventura de Sousa Santos, Law: A Map of Misreading. Toward a Postmodern Conception of Law, 14 Journal of Law \& Society 279 (1987); Sally Engle Merry, Legal Pluralism, 22 Law \& Society Review 869 (1988).

52 David Trubek, Toward a Social Theory of Law: An Essay on the Study of Law and Development, 82 Yale Law Journal 1 (1972); Marc Galanter, Why the 'Haves' Come Out Ahead: Speculations on the Limits of Legal Change, 9 Law \& Society Review 95 (1974).

${ }^{53}$ Guido Calabresi, The Cost of Accidents. A Legal and Economic Analysis (1970); Richard A. Posner, Economic Analysis of Law (1973).
} 
as the critique of juridification ${ }^{54}$ have today given way to a cacophonic contestation of the merits and limits of 'law's knowledge', its evolving nature and role. 55

Seen in this light, the search for the 'nature of law' has always been carried out with the pretentious assumption that it is or must be different, that law is - or, in the end can be different from religion, morality, and economics. But the short twentieth century has left the emerging body of law battered and torn, scarred and violated. ${ }^{56}$ In turn, our attempts at resurrecting it risk being either naïve or incredulously courageous, as the definition of law has become elusive. Should law be understood as a means of oppression, of corruption and domination, or as a promise of hope, as an instrument of liberation and emancipation? Can we recognize and understand law only in its embeddedness in a particular institiutional setting, or do we see law by its function in society ${ }^{57}$ Its multifaceted and as such fragile constitution has been associated with its paradoxical foundation ${ }^{58}$ and its impossible creation out of an act of violence. 59

Roger Cotterrell remarked in this context, that the difficulty of answering these questions has to be seen against the background of a blurring of boundaries between 'law' and

\footnotetext{
54 Philippe Nonet/Philip Selznick, Law and Society in Transition. Toward Responsive Law (1978); Gunther Teubner, Juridification - Concepts, Aspects, Limits, Solutions, in: Juridification of Social Spheres 3 (Teubner Ed. 1987).

55 Duncan Kennedy, Three Globalizations of Law and Legal Thought: 1850-2000, in: The New Law and Economic Development 19 (Trubek/Santos Ed. 2006); Boaventura de Sousa Santos, Toward a New Legal Common Sense: Law, Globalization, and Emancipation (2002); Peer Zumbansen, Law's Effectiveness and Law's Knowledge: Reflections from Legal Sociology and Legal Theory, 10 German Law Journal 417 (2009).

56 Reinhart Koselleck, Geschichte, Recht und Gerechtigkeit (1986), Frankfurt: Suhrkamp ders., Zeitschichten. Studien zur Historik 336 (2000); Upendra Baxi, The Death of Human Rights, 2nd ed. (2005).

${ }^{57}$ See Niklas Luhmann, A Sociological Theory of Law (1985).

${ }^{58}$ Gunther Teubner, How the Law Thinks: Toward a Constructivist Epistemology of Law, 23 Law \& Society Review 727 (1989); Gunther Teubner, Dealing With Paradoxes: Derrida, Luhmann, Wiethölter, in: Paradoxes and Inconsistencies in Law 41 (Perez/Teubner Ed. 2006)

${ }^{59}$ Walter Benjamin, The Critique of Violence [Zur Kritik der Gewalt, Edmund Jephcott trans.], in: Reflections: Essays, Aphorisms, Autobiographical Writings (Dementz Ed. 1978); Jacques Derrida, Force of law, 11 Cardozo Law Review 919 (1990); for an excellent discussion and homage, see Petra Gehring, Force and "Mystical Foundation" of Law: How Jacques Derrida Addresses Legal Discourse, 6 German Law Journal 151 (2005), and the contributions to the same issue (edited by Cornelia Vismann \& Florian Hoffmann).
} 
'society'. ${ }^{60}$ 'Law', he writes, 'constitutes society in so far as it is, itself, an aspect of society, a framework and an expression of understandings that enable society to exist. A sociological perspective on legal ideas is necessary to recognise and analyse the intellectual and moral power of law in this respect.' 61 Understanding law, then, as a 'social phenomenon' 62 , the distinction between law and society does indeed blur: the internal/external distinction is 'replaced by a conception of partial, relatively narrow or specialised participant perspectives on (and in) law, confronting and being confronted by, penetrating, illuminating, and being penetrated and illuminated by, broader, more inclusive perspectives on (and in) law as a social phenomenon.'63 'Sociological interpretation of legal ideas is not a particular, specialized way of approaching law, merely co-existing with other kinds of understanding. Sociology of law in this particular context is a transdisciplinary enterprise and aspiration to broaden understanding of law as a social phenomenon.' Such a perspective on law must be understood as an attempt to respond to law's own alleged lack of methodology: 'Law does not have a 'methodology of its own' and borrows methodologies from any discipline that can supply them.' ${ }^{64}$ A sociological reflection on legal ideas would be to reflect 'methodologically law's own fragmentary varied methodological characteristics'.65

Shifting our analytical focus beyond the boundaries of the nation state that has been providing the stage for the study of law in the recent past ${ }^{66}$, the here proposed framework

60 Roger Cotterrell, Why Must Legal Ideas Be Interpreted Sociologically?, 25 Journal of Law \& Society 171 (1998), 176.

61 Cotterrell, 1998, 182.

62 Cotterrell, 1998, 187: 'Sociological interpretation of legal ideas is not a particular, specialized way of approaching law, merely co-existing with other kinds of understanding. Sociology of law in this particular context is a transdisciplinary enterprise and aspiration to broaden understanding of law as a social phenomenon.'

63 Cotterrell, 1998, 188.

64 Cotterrell, 1998, 178, with reference to Jack M. Balkin, Interdisciplinarity as Colonization, 53 Washington \& Lee Law Review 949 (1996).

65 Cotterrell, 1998, 189.

${ }^{66}$ James C. Scott, Seeing like a State. How Certain Schemes to Improve the Human Condition Have Failed (1998); Niklas Luhmann, Metamorphosen des Staates, in: Luhmann, Gesellschaftsstruktur und Semantik. Studien zur Wissenssoziologie der modernen Gesellschaft 101 (1995). 
of transnational legal pluralism ${ }^{67}$ seeks to capture the methodological challenge arising for law and social theory in making sense of the emerging transnational normative order. In situating this concept in dialogue with theoretical approaches regarding transnational law'68, 'transnational commercial law'69, 'global law'70, 'law and globalisation'71, 'transnational spaces'72 and 'communities'73, 'global legal pluralism'74, 'hard versus soft law'75, 'law and social norms'76 or, 'law as product'77, the conceptual boundaries of the here pursued approach are constantly relativised and challenged by these parallel endeavours.

\footnotetext{
${ }^{67}$ Zumbansen (2009), supra, note YY; Gralf-Peter Calliess/Peer Zumbansen, Rough Consensus and Running Code: A Theory of Transnational Private Law (2010) (2010), above, ch. 2.

68 Philip C. Jessup, Transnational Law (1956); Craig M. Scott, 'Transnational Law' as Proto-Concept: Three Conceptions, 10 German Law Journal 859 (2009).
}

${ }^{69}$ Roy Goode, Usage and Its Reception in Transnational Commercial Law, 46 International and Comparative Law Quarterly 1 (1997); Ross Cranston, Theorizing Transnational Commercial Law, 42 Texas International Law Journal 597 (2007).

70 Gunther Teubner (Ed.), Global Law Without A State, 1997.

${ }^{71}$ Paul Schiff Berman, From International Law to Law and Globalization, 43 Columbia Journal of Transnational Law 485 (2005); Mathias Reimann, From the Law of Nations to Transnational Law: Why We Need a New Basic Course for the International Curriculum, 22 Penn State International Law Review 397 (2004); Peer Zumbansen, Globalization and the Law: Deciphering the Message of Transnational Human Rights Litigation, 5 German Law Journal 1499 (2004); Craig Scott, A Core Curriculum for the Transnational Legal Education of JD and LLB Students: Surveying the Approach of the International, Comparative and Transnational Law Program at Osgoode Hall Law School, 23 Penn State International Law Review 757 (2005).

72 Richard Ford, Law's Territory (A History of Jurisdiction), 97 Michigan Law Review 843 (1999); Saskia Sassen, Territory - Authority - Rights. From Medieval to Global Assemblages (2006); Saskia Sassen, The Places and Spaces of the Global: An Expanded Analytic Terrain, in: Globalization Theory. Approaches and Controversies 79 (Held/McGrew Ed. 2007); Shaunnagh Dorsett/Shaun McVeigh, Questions of jurisdiction, in: Jurisprudence of Jurisdiction 1 (McVeigh Ed. 2007); T. Alexander Aleinikoff, Transnational Spaces: Norms and Legitimacy, 33 Yale Journal of International Law 479 (2008).

${ }^{73}$ Roger Cotterrell, A Legal Concept of Community, 12 Canadian Journal of Law \& Society 75 (1997); Roger Cotterrell, Transnational Communities and the Concept of Law, 21 Ratio Juris 1 (2008).

74 Paul Schiff Berman, Global Legal Pluralism, 80 Southern California Law Review 1155 (2007); Ralf Michaels, Global Legal Pluralism, Duke Public Law \& Legal Theory Research Paper No. 259

http://papers.ssrn.com/sol3/papers.cfm?abstract_id=1430395 (2009).

75 Kenneth W. Abbott/Duncan Snidal, Hard and Soft Law in International Governance, 54 International Organization 421 (2000); Christine Chinkin, The Challenge of Soft Law: Development and Change in International Law, 38 International and Comparative Law Quarterly 850 (1989); see further the contributions to John J. Kirton/Michael J. Trebilcock (Ed.), Hard Choices, Soft Law. Voluntary Standards in Global Trade, Environment and Social Governance, 2004; Gregory Shaffer/Mark A. Pollack, Hard vs. Soft Law: Alternatives, Complements and Antagonists in International Governance, University of Minnesota Legal Studies Research Paper No. 09-23 http://ssrn.com/abstract=1426123 (2009). 
Importantly, this trajectory of legal evolution can be studied as a process of law's transnationalisation. Despite its prima facie appearance as being relevant exclusively within the nation state's framework of legal ordering, the just alluded-to scholarly projects in legal sociology, legal theory and anthropology and philosophy of law are reflective of the changing environment of legal systems. This transformation is foremost perceived as one of eroding boundaries, boundaries between form and substance ${ }^{78}$, between public and private $^{79}$ ('states' and 'markets'80), but is at its core concerned with the contestation, deconstruction and relativisation of the boundaries between law and - nonlaw. ${ }^{81}$ At the height of the regulatory state with its climactical belief in juridification and in law as social engineering 82 , law today is often seen as having become irrelevant in the face of global

76 See Posner (2000), supra, note 27; John N. Drobak (Ed.), Norms and the Law, 2006; for a critical perspective see the author of 'Order without Law', Robert C. Ellickson, Law and Economics Discovers Social Norms, 27 Journal of Legal Studies 537 (1998); see also the pertinent analysis of the inherent depoliticizing effects of the anti-regulatory efficiency claim advanced by norm proponents, by David Charny, Illusions of a Spontaneous Order: 'Norms' in Contractual Relationships, 144 University of Pennsylvania Law Review 1841 (1996), and Symposium Issue on 'Law, Economics, and Norms', published in 144 University of Pennsylvania Law Review 1643-2339 (1996); with regard to the 'norms vs regulation' conflict for example in the current debate over a Common Frame of Reference for European Private Law, see, on the one hand: Jan Smits, European Private Law: a Plea for a Spontaneous Legal Order, in: European Integration and Law 85 (Curtin/Smits/Klip/McCahery Ed. 2006), and, on the other: Martijn W. Hesselink, A spontaneous order for Europe? Why Hayek's libertarianism is not the right way forward for European private law, Centre for the Study of European Contract Law, Working Paper Series No. 2008/07 http://ssrn.com/abstract=1270566 (2008).

77 Roberta Romano, Law as Product: Some Pieces of the Incorporation Puzzle, 1 Journal of Law, Economics and Organizations 225 (1985); Erin A. O'Hara/Larry E. Ribstein, The Law Market (2009); Gralf-Peter Calliess/Hermann B. Hoffmann, Judicial Services for Global Commerce - Made in Germany?, 10 German Law Journal 115 (2009); Gralf-Peter Calliess/Hermann B. Hoffmann, Effektive Justizdienstleistungen für den globalen Handel, 42 Zeitschrift für Rechtspolitik 1 (2009); Horst Eidenmüller, Recht als Produkt, 64 Juristenzeitung [JZ] 641 (2009).

78 Duncan Kennedy, Form and Substance in Private Law Adjudication, 89 Harvard Law Review 1685 (1976); Duncan Kennedy, From the Will Theory to the Principle of Private Autonomy: Lon Fuller's 'Consideration and Form', 100 Columbia Law Review 94 (2000).

79 Morton J. Horwitz, The Transformation of American Law 1870-1960 (1992); Carol Harlow, "Public" and "Private" Law: Definition without Distinction, 43 Modern Law Review 241 (1980).

${ }^{80}$ Robert L. Hale, Coercion and Distribution in a Supposedly Non-Coercive State, 38 Political Science Quarterly 470 (1923); Frances E. Olsen, The Family and the Market: A Study of Ideology and Legal Reform, 96 Harvard Law Review 1497 (1983); for a historical discussion: Viktor Vanberg, Markt und Organisation. Individualistische Sozialtheorie und das Problem korporativen Handelns (1982).

81 Teubner (1992), supra, note 16; Gunther Teubner, The King's Many Bodies: The Self-Deconstruction of Law's Hierarchy, 31 Law \& Society Review 763 (1997); Boaventura de Sousa Santos, Toward a New Legal Common Sense: Law, Globalization, and Emancipation (2002).

${ }^{82}$ For a discussion of the U.S. development, see Orly Lobel, The Renew Deal: The Fall of Regulation and the Rise of Governance in Contemporary Legal Thought, 89 Minnesota Law Review 342 (2004); for Germany, see 
challenges. It is from this vantage point that law must be rethought and reasserted as social science, as one among other conceptual approaches to the study of modern societies. ${ }^{83}$

In the absence of world government, attempts to demarcate a legal system adequate to the 'post-national constellation'84 display above all a deep-running anxiety in the face of a perceived lack of unity, coherence and institutional and normative hierarchy ${ }^{85}$ The procedural and substantive architectures of fast-emerging transnational regulatory regimes $^{86}$ raise questions that go to the heart of any legal theory and that we have accepted to address mostly through the lens of the state. ${ }^{87}$ These questions arise around the 'politics of private law making'88 and as such concern primarily the constitutional dimensions of private ordering, that is issues of accountability, legitimacy and democratic control. ${ }^{89}$ What

Gunther Teubner, Juridification - Concepts, Aspects, Limits, Solutions, in: Juridification of Social Spheres 3 (Teubner Ed. 1987).

${ }^{83}$ Gunther Teubner, Substantive and Reflexive Elements in Modern Law, 17 Law \& Society Review 239 (1983); Santos (1987), supra, note 51; Peer Zumbansen, Law's Effectiveness and Law's Knowledge: Reflections from Legal Sociology and Legal Theory, 10 German Law Journal 417 (2009).

${ }^{84}$ Habermas (2001), supra, note 12; Jürgen Habermas, The Postnational Constellation (2001); Jürgen Habermas, A Political Constitution for the Pluralist World Society?, in: Between Naturalism and Religion. Philosophical Essays 312 (Habermas Ed. 2008).

85 William Twining, Globalisation and Legal Theory (2000), above.

86 In the world of transnational governance ' $[\mathrm{t}]$ he usual panoply of constitutional mechanisms of accountability and legitimacy which characterises liberal democratic constitutional systems is not necessarily available.' Julia Black/David Rouch, The development of global markets as rule-makers: engagement and legitimacy, Law and Financial Markets Review 218 (2008) (depicting the system of international financial governance to be distinct from nation-state based understandings of governance), 224; see also PierreHugues Verdier, Transnational Regulatory Networks and Their Limits, 34 Yale Journal of International Law 113 (2009), and the intriguing debate following this paper:

http://opiniojuris.org/2009/04/09/transnational-regulatory-networks-and-their-limits/

${ }^{87}$ Wilhelm von Humboldt, The Sphere and Duties of Government (The Limits of State Action) [orig. German, 1792, transl. Joseph Coulthard jun.] (1854); Jean-Bertrand Auby, La globalisation, Le Droit et l'État (2003), 95; Hoffmann (2008), supra, note ZZ; Stephen Bell/Andrew Hindmoor, Rethinking Governance. The Centrality of the State in Modern Society (2009);

${ }^{88}$ See only Daniela Caruso, Private Law and State-Making in the Age of Globalization, 39 New York University Journal of International Law \& Politics 1 (2006).

${ }^{89}$ For an insightful discussion, see Kenneth W. Abbott/Duncan Snidal, Strengthening International Regulation Through Transnational New Governance: Overcoming the Orchestration Deficit, 42 Vanderbilt Journal of Transnational Law 501 (2009), and Colin Scott, Reflexive governance, meta-regulation and corporate social responsibility: the 'Heineken effect', in: Perspectives on Corporate Social Responsibility 170

(Boeger/Murray/Villiers Ed. 2008); see also Amiram Gill, Corporate Governance as Social Responsibility: A 
makes these accountability and legitimacy issues, which have in part been driving the important work in 'global administrative law'90, particularly intriguing is that they underscore the degree to which the evolving transnational regulatory regimes are impressive illustrations of the constitutionalisation challenges that face the global legal order today. ${ }^{91}$ As increasingly specialised, functionally differentiated problem areas and spheres of human and institutional conduct evolve in response to a combination of external impulses and their own particular logic ${ }^{92}$, the law governing these constellations becomes deeply entwined in these complex, layered constitutions. ${ }^{93}$ Where does this definition of law leave us? Obviously, law's self-destruction began before globalization. ${ }^{94}$ Globalization,

Research Agenda, 26 Berkeley Journal of International Law 452 (2008), 471-475, 471: “Corporate selfregulation and meta-regulation, read against the New Governance literature, capture a central element in the complexity of business law. That is, these regulatory patterns accompany socio-legal changes in market economies, highlighted by the fall of state authority and the rise of private ordering." See also Christopher M. Bruner, States, Markets, and Gatekeepers: Public-Private Regulatory Regimes in an Era of Economic Globalization, 30 Michigan Journal of International Law 125 (2008) (discussing credit rating agencies and the Internet Corporation for Domain Names and Numbers-ICANN - as examples of 'public-private gatekeepers' and their government-like exercise of regulatory authority-id, at 129, 165).

90 Benedict Kingsbury/Nico Krisch/Richard B. Stewart/Jarrod Wiener, Global Governance as Administration-National And Transnational Approaches to Global Administrative Law, 68 LAW \& CONTEMPORARY PRoBlems 1 (2005); Kalypso Nicolaidis/Gregory Shaffer, Transnational Mutual Recognition Regimes: Governance without Global Government, 68 LAW \& CONTEMPORARY PROBLEMS 263 (2005); for critical-sympathetic comments on this project, see Carol Harlow, Global Administrative Law: The Quest for Principles and Values, 17 EuROPEAN JoURNAL OF INTERNATIONAL LAW 187 (2006), B.S. Chimni, Co-option and Resistance: Two Faces of Global Administrative Law, 37 New York University Journal of International LaW \& Politics 799 (2005), and Susan Marks, Naming Global Administrative Law, 37 NEW York University JouRnAl of InTERnational LAW AND Politics 995 (2006).

${ }^{91}$ Christian Walter, Constitutionalizing (Inter)national Governance - Possibilities and Limits to the Development of an Inernational Constitutional Law, 44 GERMAN YEARBOOK OF INTERNATIONAL LAW 170 (2001); Christian Joerges, The Challenges of Europeanization in the Realm of Private Law: A Plea for a New Legal Discipline, 14 Duke Journal of Comparative \& International Law 149 (2004); David Kennedy, A New World Order: Yesterday, Today, Tomorrow, 4 TRANSNATIONAl LaW \& CONTEMPORARY PRoblems 329 (1994)

${ }^{22}$ See the examples in Volkmar Gessner/Ali Cem Budak (Ed.), Emerging LEGAL CERTAinTY: EMPIRICAL StudiES on THE Globalization OF LAW, 1998, and Andreas Fischer-Lescano/Gunther Teubner, Regime-Collisions: The Vain Search for Legal Unity in the Fragmentation of Global Law, 25 MiCHIGAN JOURNAL OF INTERNATIONAL LAW 999 (2004).

93 Gunther Teubner/Peter Korth, Two Kinds of Legal Pluralism: Collision of Laws in the Double Fragmentation of World Society, in: Regime InTERACTION In InTERnATIONAL LAW: THEORETICAL AND PRACTICAL ChaLLENGES forthcoming (Young Ed. 2009), Ms. at 5 (available at:

http://papers.ssrn.com/sol3/papers.cfm?abstract id=1416041): 'Unitary global law reproduces itself through legal acts which are guided by different programs but are in the end oriented towards the binary code legal/illegal. The unity of global law is just not, as in the nation state, based on the consistency of legal norms structurally secured by the hierarchy of the courts: rather, it is process-based, deriving simply from the modes of connection between legal operations, which transfer binding legality between even highly heterogeneous legal orders.'

${ }^{94}$ But see WiLLIAM TWining, GLOBALISATION AND LEGAL THEORY (2000). 
differently understood, would provide for a label depicting another stage of reflection on the relationship between law and its other. The predominance of law's institutionalisation in the state during the $19^{\text {th }}$ and $20^{\text {th }}$ centuries casts a long shadow over our present attempts to imagine law. The challenge of law after, in the shadow of the $20^{\text {th }}$ century welfare state is its functional diffusion and normative evaporation. To be sure, this temporalisation ('after') indicates a shift of paradigm, a conclusion and abdication of a dominant concept, rather than a historical development of a series of institutional framework that comprehensively replaces the preceding models of the state and modes of legal thinking. ${ }^{95}$

When referring to 'global governance', scholars often associate a dramatic disembedding of law and its institutional architecture. ${ }^{96}$ But, the - relative - loss of a reliable and comprehensive legal infrastructure is accompanied by an increasingly intensifying debate around an evolving global legal consciousness, in particular with regard to human rights. ${ }^{97}$ Global governance is as such understood to have further opened the windows to a world 'out there' of injustice, unequal distribution and grave rights abuses ${ }^{98}$, a claim, however, fiercely contested from scholars and practitioners 'on the ground'.99 As illustrated, for example, in the continued interest in the 'constitutionalization' of international law ${ }^{100}$, the

\footnotetext{
${ }^{95}$ For a parallel application of such a perspective, see DunCAN KENNEDY, THE RISE AND FALL OF CLASSICAL LEGAL THOUGHT (1975) (2006).

${ }_{96}$ See eg Ulrich Sieber, Rechtliche Ordnung in einer Globalen Welt, 41 RECHTSTHEORIE 151 (2010).

${ }^{97}$ See Michel Rosenfeld, Rethinking constitutional ordering in an era of legal and ideological pluralism, 6 InTERNATIONAL JOURNAL OF CONSTITUTIONAL LAW 415 (2008), and Christopher McCrudden, A Common Law of Human Rights? Transnational Judicial Conversations on Constitutional Rights, 20 OXFORD JOURNAL OF LEGAL STUDIES 499 (2000)

98 Upendra Baxi, The Death of Human Rights, 2ND ed. (2005).

${ }^{99}$ See eg Boaventura de Sousa Santos, The Processes of Globalisation, EuRozine http://www.eurozine.com/pdf/2002 (2002), and Sally Engle Merry, Measuring the World: Indicators, Human Rights, and Global Governance, in: Law in Transition: RIghts, Development and Transitional Justice forthcoming (Zumbansen/Buchanan Ed. 2009).

100 For a critical discussion, see Theodor Schilling, Constitutionalization of General International Law - An Answer to Globalization? Some Structural Aspects, NYU JeAn MonNet Program Working PAPER http://www.jeanmonnetprogram.org/fellowsforum/documents/SchillingForumPaper020405.pdf (2005), Sol Picciotto, Constitutionalizing Multilevel Governance?, 6 InTERnATIOnAL Journal of Constitutional LaW 457
} 
question whether there is any pervasive role for law in a globalised world remains at the core of the present engagement with global governance issues. As suggested above, the complexity which is inherent to the differentiation of law and non-law in regulatory governance and for which the evolution of modern states give ample illustration, is further exacerbated in the global context. This means that a crisis, or 'exhaustion' of law cannot be depicted as a consequence of globalization, but as an inherent feature of law's evolution in its relation to society. To reiterate the central thesis of this a: the alleged crisis of law and legal regulation, whether depicted as a loss of state sovereignty or as a problem of lacking (democratic, political) accountability ${ }^{101}$ and legitimacy ${ }^{102}$ in the global context, has to be understood as a particular amplification of a problem with law that has long been in the coming. In that respect, it can be shown that many of our present concerns about the fate of law in relation to a continuing transformation of the state and the herewith connected challenges to 'models of democracy' and issues of legitimacy and accountability ${ }^{103}$ must be assessed against the background of a reconstruction of legal evolution in the national, local context. Without suggesting that the legitimacy and regulatory challenges connected with the 'amorphous' concept of global governance ${ }^{104}$ are exact mirror reflections of locally experienced moments of exhaustion ${ }^{105}$, there is a particular role to be played by local,

(2008), and Martin Loughlin, What is Constitutionalization?, in: The TwiLiGHT of ConstituTIONALISM? 47 (Dobner/Loughlin Ed. 2010).

${ }^{101}$ Jerry Louis Mashaw, Accountability and Institutional Design: Some Thoughts on the Grammar of Governance, YAlE LAW SCHOOL ReSEARCH PAPER No. 116 http://papers.ssrn.com/abstract=924879 (2007)

102 Julia Black, Constructing and Contesting Legitimacy and Accountability in Polycentric Regulatory Regimes, LSE LAW, SOCIETY AND ECONOMY WORKING PAPERS 2/2008 http://ssrn.com/abstract=1091783 (2008), associating legitimacy and accountability concerns of transnational regulatory regimes with a set of "functional, democratic, normative" challenges.

103 David Held, Democratic Accountability and Political Effectiveness from a Cosmopolitan Perspective, 39 GOVERNMENT AND OPPOSITION 364 (2004)

${ }^{104}$ For a lament of the concept's shortcomings in providing guidance for the development of sustainable and effective regulatory instruments, see Armin Bogdandy/Philipp Dann/Matthias Goldmann, Developing the Publicness of Public International Law, 9 GERMAN LAW JOURNAL 1375 (2008); in contrast, see David Held, Reframing Global Governance: Apocalypse Soon or Reform!, in: GLOBALIZATION THEORY. APPROACHES AND CONTROVERSIES 240 (Held/McGrew Ed. 2007), at 245-6, 249-254, and Mathias Koenig-Archibugi, Global governance, in: THE HANDBOOK OF GLOBALISATION 318 (Michie Ed. 2003), highlighting the interdisciplinary challenges that are captured in the term.

105 Jürgen Habermas, The New Obscurity: The Crisis of the Welfare State and the Exhaustion of Utopian Energies [1985], in: The New Conservatism. Cultural Criticism and the Historians' Debate [ED. AND transl. By Shierry WEBER NiCHOLSEN] 48 (Habermas Ed. 1989) 
domestic regulatory experiences for the conceptualisation of global governance regimes. The role of law occupies a particularly challenging place in this inquiry, in particular because the rise of globalization is so often associated if not with the demise of law ${ }^{106}$, then with an immense pressure on law and legal institutions. In contrast, what is argued here is that globalization processes can be understood as an invitation to reflect on the connections between our attempts to make sense of a fragmented global, transnational normative order and our particular, yet anything but homogenous experiences with law and regulation on the national level. In short, then, the article contends that globalisation does not pose the first advent of a 'crisis of law', understood as a tool of regulation. Instead, the varied history of law reveals the intricate combination of hubris and fragility, violence and vulnerability that underlies the idea and experience of law.

\section{Methodological Consequences}

A study of law in the context of evolving global governance debates, then, prompts parallel efforts of introspection (say, regarding the 'definition' and the function of law) and of demarcation (for example, regarding the different qualities between legal, political and economic governance). Such efforts, however, are being pursued against the background of a still tentative description of the transnational regulatory landscape. While, for example from the perspective of comparative law, there is much to learn from studying law against the background of a particular, national, historical context ${ }^{107}$, the transnational dimension

\footnotetext{
106 See, for example, the intriguing melancholic observation by NiKLAS LUHMANN, LAW AS A SoCIAL SYSTEM (K Ziegert TRANSL., F KASTNER, D SChifF, R NOBlES, R Ziegert EDS.) (2004), 497.

107 In this regard, see the helpful comparative reconstructions of public and private law concepts by Nils Jansen/Ralf Michaels, Private Law and the State. Comparative Perceptions and Historical Observations, 71 RABELS ZEITSCHRIFT FÜR AUSLÄNDISCHES UND INTERNATIONALES PRIVATRECHT [RabelsZ] 345 (2007), reprinted in: Jansen \& Michaels edS., Beyond the State: Rethinking Private LaW (2008), 15-67
} 
challenges the tendency in comparative law to study distinct legal cultures. ${ }^{108}$ Much suggests that the particular nature of the transnational arena defeats our attempts at understanding the relation between the national and the 'post-national constellation'109 as a linear one - either on a chronological or a systematic level. ${ }^{110}$ But, at the same time, the evolving transnational nature of regulatory regimes as, for example, in labour ${ }^{111}$ or corporate law ${ }^{112}$, presents itself not as an opposition or negation, but as a challenge to reassert the place and role of law. Reconceiving of law as transnational suggests that domestic experiences with law are crucial reference points. Yet, they cannot serve as reference points of institutional or normative design, which we could simply employ and transpose into the transnational arena. Instead, this approach must point towards two investigative strands. One is that the inquiry into the evolution and, eventually, the socalled 'crisis' of law as regulation of social activity has to attempt the reconstruction as an ironic project that is concerned with the meaning and aspiration of law - over time and space. ${ }^{113}$ This constellation can be grasped as the relation or tension between law and nonlaw, between legality and legitimacy, between law and justice, society, or other. ${ }^{114}$ The reconstruction of local (eg national) experiences with law as constantly challenged by its

108 This is elaborated in Peer Zumbansen, Transnational Comparisons: Theory and Practice of Comparative Law as a Critique of Global Governance, in: THEORY AND PRACTICE OF COMPARATIVE LAW forthcoming (Bomhoff/Adams Ed. 2011).

${ }^{109}$ Habermas (2001), supra, note 12

110 See the succinct observations by William Twining, Globalisation and Legal Theory (2000) with regard to the challenges to jurisprudence and by Jürgen Osterhammel/Niels P. Petersson, Globalization: A Short History (2004) with regard to the interdisciplinary challenges of studying and deciphering 'globalization'. "The fact that historians assert with calm detachment that this phenomenon has existed for a long time does not preclude the need to make a political assessment of its impact on the present." Id., at 150.

111 Adelle Blackett, Global Governance, Legal Pluralism and the Decentered State: A Labor Law Critique of Codes of Corporate Conduct, 8 Indiana JouRnal of Global LEgal Studies 401 (2001); Harry W. Arthurs, Labor Law Without the State, 46 UnIVERSITY OF TORONTO LAW JOURNAL 1 (1996)

${ }^{112}$ Simon Deakin, Reflexive Governance and European Company Law, CLPE RESEARCH PAPER SERIES (http://www.comparativeresearch.net/papers.jsp) \& CAMBRIDGE CENTRE FOR BUSINESS RESEARCH, WORKING PAPER No. 346 http://www.cbr.cam.ac.uk/pdf/wp346.pdf (2007); Larry Cata Backer, Private Governance, Soft Law, and the Construction of Polycentric Networks for the Regulation of Transnational Corporations, 17 INDIANA JOURNAL OF GLOBAL LEGAL STUDIES forthcoming (2011)

${ }^{113}$ Hereto, in more detail: Zumbansen (2008), supra, note 31.

114 See, for example, David Trubek, Toward a Social Theory of Law: An Essay on the Study of Law and Development, 82 Yale LaW Journal 1 (1972); Robert M. Cover, Nomos and Narrative, 97 HaRvard LaW Review 4 (1983); Jacques Derrida, Force of law, 11 Cardozo Law REview 919 (1990). See also Gunther Teubner, Selfsubversive Justice: Contingency or Transcendency Formula of Law?, 72 MODERN LAW REview 1 (2009). 
opposite or its foundations, embeddedness or contestations forms one strand of the following inquiry. ${ }^{115}$

The second investigative strand is to return to the original starting point of our reflections of how globalization can be said to challenge law. In this dimension we are concerned with the task of adequately incorporating or, perhaps even acknowledging the gap between the particular context in which norms and the normative environments have evolved locally on the one hand, and the emerging, allegedly unruly spaces of normative order on the global level on the other. Against this background, the methodological dimension of transnational law reasserts itself. Approaching transnational law from a methodological perspective should help us in refraining from too quickly depicting the 'transnational' as a distinct regulatory space, which would differ from the national and the international due to its deterritorial scope and its hybrid, public-private constitution. Instead, transnational law emerges as a particular perspective on law as part of a society that itself cannot sufficiently be captured by reference to national or de-nationalized boundaries. The transnational dimension does not arise with respect to territorial or, jurisdictional confines, but from a reconstruction of the form and function of law deep within highly specialized areas of societal activity.

While this uncoupling of social systems from a state-associated framework of political, economic and legal order certainly presents a dramatic challenge to state-based theories of law its real gist lies in fact elsewhere. The uneasy relationship between 'society' and 'world society', between the national and the global, should not be seen as a threat but as an element which is inherent to the constitution of legal spaces. From this perspective, transnational refers to the 'other' of the law, which challenges but simultaneously recognizes its locally learned relations to concrete structures of embeddedness, to

\footnotetext{
115 See, for example, Santos (1987), supra, note 51.
} 
particular experiences of historical evolution and contextual differentiation. ${ }^{116}$ Inspired by the analysis offered by the sociologist Saskia Sassen ${ }^{117}$, transnational law can be conceived of as a way of questioning and reconstructing the project of law between places and spaces, precisely because it helps to relativize law's association with particular institutional frameworks. ${ }^{118}$ At the same time, the tension between law's grounding in concrete geographical and historical places and its evolution in spatial terms ${ }^{119}$ prompts a careful look at the evolving relation between law, critique and politics. ${ }^{120}$

\section{Things We Lost - Things We Ought to Remember}

Such a look back at 'places' reveals intriguing parallels between current global governance concerns and older debates around the effectiveness of legal regulation in complex societies.121 Clearly, the hybridity of regulatory instruments, which many global governance scholars observe today, was a well-known feature of legal regulation as studied by legal sociologists and legal pluralists decades ago. In that regard, Sally Moore's analysis of law as being constituted in part by social norms, routines, customs and practices and, at the same time, by hard legal regulation, proved of vital importance in opening our eyes for the intricate relations between the regulator and concrete, local, intimate social spaces. ${ }^{122}$ Foreshadowing later calls for a recognition of the regulatory powers of 'social norms'123,

\footnotetext{
116 For a comparative approach from the perspective of legal geography, see Richard Ford, Law's Territory (A History of Jurisdiction), 97 Michigan LAW REviEw 843 (1999), and Mariana Valverde, Jurisdiction and Scale: Legal 'Technicalities' as Resources for Theory, 18 SocIAL \& LEGAL STUDIES 139 (2009).

117 Saskia Sassen, The State and Globalization, in: GovernAnCE IN A GLobALIzING World 91 (Nye/Donahue Ed. 2000); Saskia Sassen, Territory - Authority - Rights. From Medieval to Global Assemblages (2006)
}

118 For further discussion, see Gunther Teubner, Fragmented Foundations: Societal Constitutionalism beyond the Nation State, in: The Twilight of ConstitutionaliSM? 327 (Dobner/Loughlin Ed. 2010).

119 See eg Saskia Sassen, The Embeddedness of Electronic Markets: The Case of Global Capital Markets, in: THE Sociology of FinANCIAL MARKets 17 (Cetina/Preda Ed. 2005).

120 Very helpful in this regard: Hauke Brunkhorst, Constitutionalism and Democracy in the World Society, in: The Twilight of ConstitutionAlism? 179 (Dobner/Loughlin Ed. 2010), and Petra Dobner, More Law, less Democracy? Democracy and Transnational Constitutionalism, in: THE TWILIGHT OF ConSTITUTIONALISM? 141 (Dobner/Loughlin Ed. 2010).

121 Moore (1973), supra, note 16

122 For a discussion and elaboration, see only John Griffiths, What is Legal Pluralism?, 24 JOURNAL OF LEGAL PluRALISM AND UNOFFICIAL LAW 1 (1986)

123 Posner (2000), supra, note 27 
scholars disenchanted with 'rights'-based interventionism called for extra-legal activism ${ }^{124}$ and de-legalization. ${ }^{125}$

On both sides of the Atlantic, the responses to the financially and normatively exhausted Welfare State ${ }^{126}$ soon split into progressive ${ }^{127}$ and conservative ${ }^{128}$ camps, and this context is worth bearing in mind when assessing, for example, today's academic and political proposals in the wake of the 2009 financial crisis, but also law's role in global governance more generally. In the context of the late 1970s and early 1980s, that saw a far-reaching crumbling of social-democratic policy and a growing scepticism with Keynesian economics, a fairly ambitious theoretical proposal was made that aimed at the resituating of law into a more accentuated model of society: in this model, which did not lend itself to a straightforward ideological appropriation, society is composed of intersecting, but separated communications that are each constituted by a distinct terminology ('code'). Law was to be understood as one of these social systems - along with 'economy', 'politics', 'religion', or 'art'. ${ }^{129}$ On the basis of this position, the concept of 'reflexive law' was proposed as a form of law marked above all by a crucial exposure to and immersion into its surrounding systems, while it remained 'operationally' closed. Due to its 'cognitive' openness, however, law must constantly receive impulses, 'irritations' and, relying on its autopoietic nature, formulate legal responses, i.e. continue its systematic operation. In the face of the weakening welfare state and the growing frustration with ineffective, undemocratic, and over-generalizing and paternalising regulatory laws, the concept of reflexive law was offered to explain the

\footnotetext{
124 For a brief historical account, see Orly Lobel, The Paradox of Extralegal Activism: Critical Legal Consciousness and Transformative Politics, 120 HARVARD LAW REVIEW 937 (2007).

125 Marc Galanter, Justice in many rooms: Courts, Private Ordering and Indigenous Law, 19 JOURNAL OF LEGAL PLURALISM 1 (1981)

126 Habermas (1989), supra, note 105

127 Hubert Rottleuthner, The Limits of Law: The Myth of a Regulatory Crisis, 17 InTERNATIONAL JOURNAL OF THE SOCIOLOLOGY OF LAW 273 (1989)

128 Friedrich A. HAyeK, The Mirage of Social Justice [LAW, LEgislation And Liberty. A new STATEMENT OF the LIBERAL PRINCIPLES OF JUSTICE AND POLITICAL ECONOMY, VOL. 2] (1976)

129 Luhmann (1989), supra, note 22; LUHMANN (2004), supra, note 106
} 
particular challenge and form of legal regulation in a complex world. Its not uncontested core consisted of understanding law as being taken out of a learned institutional context made up of official institutions authoritatively creating state-originating laws and, instead, to be forced to reassert itself in highly diversified complex environments. This radicalization of law's functional orientation constitutes a new stage in the assessment of law's institutional form, as it has been learned over time. Whereas law is still today most often associated with the state, already the legal sociological work at the turn of the century as well as the legal pluralist work since the 1960s and 1970s had long questioned this tight coupling of law with the state.

Yet, the exuberant turn away from the state and to the market at the end of the $20^{\text {th }}$ century can be seen as smartly employing the very methodological orientations that had informed the reconstructive legal projects in the face of a financially and normatively exhausted welfare state ${ }^{130}$ in the 1980 s. The fragile reconstructions of law through the concepts of responsive or reflexive law on both side of the Atlantic eventually fed into a large scale rejection of state 'intervention' all throughout the 1980s and 1990s. The politically progressive scholars in the 1970s and 80s had turned to alternative modes of legal regulation seeking to translate law's generality into contextual, learning forms of sociolegal regulation. Their hope had been thereby to save the political ambitions of the welfare state, while continuing the socio-political debate over the substance and direction of political intervention. In contrast, today's neo-formalism and neo-functionalism threatens to cut the ties between current quest to answer the challenges of globalization and the previous struggles over law and politics. Its proponents characterise legal regulation as inappropriately policy-driven and as undue infringement of the societal actors' capacity to regulate their own affairs autonomously. ${ }_{131}$

In the clout of neo-formalism and neo-functionalism, which has been characterising legal policy in recent years, a heavy reliance on arguments of 'necessity,' of 'objectivity' and 'naturalness' came to prepare the ground for a functionalist interpretation and application

\footnotetext{
${ }^{130}$ Habermas (1989), supra, note 105

131 See, for example, Robert E. Scott/George G. Triantis, Anticipating Litigation in Contract Design, 115 YALE LAW JOURNAL 814 (2006).
} 
of legal norms in politically charged contexts experiencing fundamental shifts from public to private regulation. The attack on contract adjudication and governmental 'intervention' that accompanied these developments regularly depicted a market as originally existing without politics, without government regulation. ${ }^{132}$ This depiction of the market and the state as separate worlds formed troubling alliances with policy recommendations promoting the privatisation of public services that were often fuelled by arguments of efficiency and cost reduction. ${ }^{133}$ Yet, whether or not, and in which forms, private actors assume formerly public regulatory functions, represents the outcome of political choices and of other socio-economic developments, that are unfolding at both the national and transnational level. ${ }^{134}$ The allegedly available 'fresh start' for societal self-regulation without state interference -at least as it was widely perceived until the fall of 2008 - stood in stark contrast to the observation already made decades ago - that when market actors are enabled and empowered to exercise their private autonomy they are exercising this freedom based on public deliberation and consensus. ${ }^{135}$

While there is considerable reason to believe, today, that we have entered a stage in the assessment of state and market where we have to carefully turn our attention again to the long and winded history of this relationship ${ }^{136}$, the identification of starting points for a reconstructive project is far from obvious. ${ }^{137}$ As the treacherous denationalisation ${ }^{138}$ of

\footnotetext{
132 Frank H. Knight, Some Fallacies in the Interpretation of Social Cost, 38 QUARTERLY JOURNAL OF ECONOMICS 582 (1924). "The system as a whole is dependent on an outside organization, an authoritarian state, made up also of ignorant and frail human beings, to provide a setting in which it can operate at all." Id.

${ }^{133}$ For a critique, see Alfred C. Aman Jr., The Limits of Globalization and the Future of Administrative Law: From Government to Governance, 8 InDIANA JoURNAL OF GLOBAL LEGAL STUDIES 379 (2001).

134 This led Philip Jessup to his capturing three dramas about constellations within and beyond the nation state that involve parallel questions of democracy and participation. See Philip C. Jessup, Transnational LaW (1956).

135 Morris R. Cohen, Property and Sovereignty, 13 CORNELL LAW QUARTERLY 8 (1927).

136 Paul Krugman, The Return of Depression Economics and the Crisis of 2008 (2009); Robert Skidelsky, Keynes. The RETURn OF THE MASTER (2009).

${ }^{137}$ See, for example, Jens Beckert, The Great Transformation of Embeddedness. Karl Polanyi and the New Economic Sociology, MAX-PLANCK-InSTITUT FÜR GESELlSCHAFTSFORSCHUNG/MAX-PLANCK-INSTITUTE FOR THE STUDY OF Societies, MPIFG Discussion PAPER 07/1 (2007); Michael J. Piore, Second Thoughts: On Economics, Sociology, Neoliberalism, Polanyi's Double Movement and Intellectual Vacuums, SOCIETY FOR THE ADVANCEMENT OF Socio-
} 
regulatory areas continues to pose tremendous conceptual problems for state-based theories of law, we must aim at combining our methodological inquiry into the nature of transnational law with a bold reconstruction of critical perspectives from which to discuss the need for 'better', 'more efficient', 'tougher' etc regulation, as is demanded today in the face of what continues to unfold as a dramatic financial and economic crisis.

\section{E. The Evolving Nature of Transnational Governance Regimes}

The ambivalent politics of this shift between 'national' and 'transnational' perspectives is today amply illustrated by concrete examples of spatial regulatory regimes, by which we identify those regulatory regimes which originate through a combination of institutional and normative formation that transcends jurisdictional borders and combines national \& international, public and private actors. ${ }^{139}$ This is evidenced, for example, in the case of corporate governance regulation: as we continue to study corporate governance norms through nationally oriented textbooks and case law, we soon learn how the rules and instruments we are dealing with are products of a far-reaching, fundamental transformation of previously jurisdictionally defined regulatory landscapes. As corporate law is being shaped by a complex mix of public, private, state- and non-state-based norms, principles and rules, generated, disseminated and monitored by a diverse set of actors ${ }^{140}$ and experts ${ }^{141}$, even the most casual look at today's corporate governance debates reveals two important aspects: one is the way in which the analysis of contemporary corporate

ECONOMiCS, PRESIDENTIAL AdDRESS JULY 22 (2008), available at: http://web.mit.edu/ipc/publications/pdf/08$\underline{004 . p d f}$

138 Saskia Sassen, Globalization or denationalization?, 10 REVIEW OF INTERNATIONAL Political EConomy 1 (2003); see also Saskia Sassen, The Embeddedness of Electronic Markets: The Case of Global Capital Markets, in: The Sociology of Financial Markets 17 (Cetina/Preda Ed. 2005).

${ }^{139}$ For an illustration in the case of corporate law, see Zumbansen (2011), supra, note 11.

140 See, for example, the overview at www.ecgi.org.

141 Johannes Köndgen, Privatisierung des Rechts. Private Governance zwischen Deregulierung und Rekonstitutionalisierung, 206 ARCHIV FÜR DIE CILIVILISTISCHE PRAXIS [AcP] 477 (2006); Thomas M.J. Möllers, Europäische Methoden- und Gesetzgebungslehre im Kapitalmarktrecht. Vollharmonisierung, Generalklauseln und soft law im Rahmen des Lamfalussy-Verfahrens zur Etablierung von Standards, ZEITSCHRIFT FÜR EuRoPÄISCHES PRIVATRECHT 480 (2008), 485; Peer Zumbansen, The Privatization of Corporate Law? Corporate Governance Codes and Commercial Self-Regulation, JURIDIKUM 136 (2002b) 
governance regulation can help us become sensitive to the emerging, new framework within which corporate governance rules are evolving, a framework which is constituted by a combination of local and transnational actors and norms, connected through 'networks' and 'migrating' standards. ${ }^{142}$

The contested political dimensions as well as the high degree of technicality of the regulatory subjects of transnational regulatory areas ${ }^{143}$ present a formidable challenge to traditional, regulatory theories of law. ${ }^{144}$ As alluded to above, it is this intricate combination of political ambivalence and technical specialization of transnational regulation, which prompts a renewed reflection on the relation between regulatory law and differentiated areas of societal activity. Legal sociology and legal pluralism, in particular, have long been developing tools to scrutinize the tension between 'official' and 'inofficial' norm creation, between 'hard' and 'soft' law, between what at least in the West has often been depicted as a juxtaposition of state law making on the one hand and 'private ordering' or 'social norms' on the other. This constellation prompted legal sociologists 'to investigate the correlations between law and other spheres of culture.'145 Revisiting the legal pluralist work in the second half of the twentieth century, for example the contributions from scholars such as Sally Moore ${ }^{146}$, Marc Galanter ${ }^{147}$, Stewart Macaulay ${ }^{148}$,

142 See Nils BRUnSSON/BENGT JACOBSSON, A WoRLD OF STANDARDS (2000); Robert Wai, Transnational Private Law and Private Ordering in Contested Global Society, 46 HARVARD InTERNATIONAL LAW JOURNAL 471 (2005).

${ }^{143}$ For a recent overview, see the excellent collection in: Sanjeev Khagram/Peggy Levitt (Ed.), THE TRANSNATIONAL STUDies READER. InTERSECTIONS \& InNOVATIONS, 2008; see also Janet Joven Levit, Bottom-Up International Lawmaking: Reflections on the New Haven School of International Law, 32 YALE J. INT'L L. 393 (2007), and the contributions by Alexia Herwig, Perez, von Bernstorff, Ladeur and Scott \& Wai in: Christian Joerges/Inger-Johanne Sand/Gunther Teubner (Ed.), Transnational GovernancE AND Constitutionalism, 2004.

${ }^{144}$ See Colin Scott, Regulating Everything, Inaugural Lecture, University College Dublin, School of Law, 26.2.2008 http://geary.ucd.ie/mapping/images/Documents/RegEverything.pdf (2008).

145 Eugen Ehrlich, Fundamental Principles of the Sociology of LAW (ORIG. PUblished in GeRman AS GrundLEgung DER Soziologie DES RECHTS, 1913) (1962), 486-506 "The Study of the living law"; Georges Gurvitch, Sociology of Law (orig. published in French as Problèmes de la sociologie du droit) (1947); Max Rheinstein, Review: Two Recent Books on Sociology of Law [reviewing Timasheff's 'Introduction' and Gurvitch's 'Elements'], 51 ETHICS 220 (1941), 221-2

146 Moore (1973), supra, note 16 
Boaventura de Sousa Santos ${ }^{149}$ or Gunther Teubner ${ }^{150}$, provides a rich background for contemporary assessments of 'hybrid legal spaces'151 that cannot sufficiently be captured through references to local or national contexts. A distinctly transnational legal pluralist lens allows us to study such regimes not as entirely detached from national political and legal orders, but as emerging out of and reaching beyond them. The transnational dimension of hybrid regulatory actors and newly emerging forms of norms radicalizes their 'semi-autonomous' nature (Moore) and we begin to conceive of regulatory spaces as being marked by a dynamic tension between formal and informal norm-making processes.

But, what about the politics of transnational regulation?152 Again, an example taken from the corporate law context may serve as an illustration: the much lamented, regulatory 'failure' of traditional, state-based legal-political intervention into multinational corporations (MNC) ${ }^{153}$ has long been serving as an argument for the need to develop either distinctly 'post-national', institutionalized governance forms or to further strengthen the grip of self-regulatory and soft instruments, which have only voluntary binding nature. ${ }^{154}$ Mirroring the complex, hard-to-navigate landscape of border-crossing corporate activity, the proposed conceptual approaches vary greatly. Instead of pointing towards the creation of a coherent regulatory framework, theoretical proposals for transnational regulation

\footnotetext{
${ }_{147}$ Marc Galanter, Justice in many rooms: Courts, Private Ordering and Indigenous Law, 19 JouRnAL OF LEGAL PLURALISM 1 (1981)

148 Stewart Macaulay, Private Government, in: LAW AND THE SoCIAL SCIENCES 445 (Lipson/Wheeler Ed. 1986)

${ }^{149}$ Santos (1987), supra, note 51

150 Teubner (1992), supra, note 16; Gunther Teubner, Societal Constitutionalism: Alternatives to State-Centred Constitutional Theory?, in: ConstituTionalism And TRANSNATIONAL GovernanCE 3 (Joerges/Sand/Teubner Ed. 2004)

151 Paul Schiff Berman, Global Legal Pluralism, 80 S. CAL. L. Rev. 1155 (2007), 1155

152 See only David Schneiderman, Transnational Legality and the Immobilization of Local Agency, 2 Annual Review of Law and Social Sciences 387 (2006), and Peter Fitzpatrick, Terminal Legality? Human Rights and Critical Being, in: Critical Beings. LAW, NATiOn AND THE Global SubJECT 119 (Fitzpatrick/Tuitt Ed. 2004)

153 David Kinley/Junko Tadaki, From Talk to Walk: The Emergence of Human Rights Responsibilities for Corporations at International Law, 44 VA. J. INT'L L. 931 (2004); David Vogel, The Private Regulation of Global Corporate Conduct, in: THE Politics of Global Regulation 151 (Mattli/Woods Ed. 2009); Larry Cata Backer, Private Governance, Soft Law, and the Construction of Polycentric Networks for the Regulation of Transnational Corporations, 17 INDIANA JOURNAL OF GLOBAL LEGAL STUDIES forthcoming (2011)

154 Blackett (2001), supra, note 111; Harry W. Arthurs, Reinventing Labor Law for the Global Economy: The Benjamin Aaron Lecture, 22 BerKelEY Journal OF EMPLOYMENT AND LABOR LAW 271 (2001)
} 
range from ideas concerned with world courts ('global jurisdiction'155), and 'torture as tort' as well as 'transnational civil human rights litigation'156, to 'scandalization' (global shaming ${ }^{157}$ ) and soft law instruments, self-binding norms, codes of conduct and best practices. ${ }^{158}$

These efforts illustrate the frustration with the lack of accountability, access to justice and democratic legitimacy of the evolving regulatory frameworks ${ }^{159}$, a frustration which has become increasingly accentuated in the context of a seemingly irreversible shift 'from government to governance'.160 As transnational governance regimes, fields such as corporate governance, labour law ${ }^{161}$, capital market law, or consumer protection law ${ }^{162}$ are increasingly marked by the existence of opt-out clauses and self-regulation mechanisms rather than being defined by enforceable hard-law rules. Meanwhile, it seems evident that a simple return to calls for 'more' state interventionism is not a viable option in light of the transnational nature of regulation today. Such a return is elusive, as the state can no longer be depicted as the last safe haven, which etatists - such as Carl Schmitt and his pupils in

155 Paul Schiff Berman, Towards A Cosmopolitan Vision Of Conflict Of Laws: Redefining Governmental Interests In A Global Era, 153 U. PA. L. Rev. 1819 (2005)

156 Craig M. Scott, Introduction to Torture as Tort: From Sudan to Canada to Somalia, in: ToRTURE AS TORT 3 (Scott Ed. 2001); Craig M. Scott, Translating Torture into Transnational Tort: Conceptual Divides in the Debate on Corporate Accountability for Human Rights Harms, in: TORTURE AS TORT 45 (Scott Ed. 2001)

${ }^{157}$ Andreas Fischer-Lescano, Globalverfassung, Verfassung der Weltgesellschaft, 88 ARCHIV FÜR RECHTS- UND SOZIALPHILOSOPHIE [ARSP] 349 (2002)

158 Oren Perez, Ecological Sensitivity and Global Legal PluRalism (2004)

${ }^{159}$ See Christiana Ochoa, The Relationship of Participatory Democracy to Participatory Law Formation, 15 INDIANA JOURNAL OF GLOBAL LEGAL STUDIES 5 (2008).

160 Jason M. Solomon, Law and Governance in the 21st Century Regulatory State, 86 TEXAS LAW REvIEW 819 (2008)

161 Alain SuPIOT, AU-DELÀ DE L'EMPLOI. TRANSFORMATION DU TRAVAIL ET DEVENIR DU DRoIT DU TRAVAIL EN EUROPE. RAPPORT POUR LA COMMISSION EUROPÉENNE. (1999); Robert O'Brian, The difficult birth of a global labour movement, 7 REv. INT'L Pol. ECon. 514 (2000); Claire Methven O'Brien, Reframing Deliberative Cosmopolitanism: Perspectives on Transnationalisation and Post-national Democracy from Labor Law, 9 GERMAN LAW JOURNAL 1007 (2008)

162 Gralf-Peter Calliess, Reflexive Transnational Law. The Privatisation of Civil Law and the Civilisation of Private Law, 23 ZeITSChRIFT FÜR ReChTSSOZIOlogie 185 (2002); GRALF-PETER CALLIESS, GRENZÜBERSCHREITENDE VERBRAUCHERVERTRÄGE. RECHTSSICHERHEIT UND GERECHTIGKEIT AUF DEM ELEKTRONISCHEN WELTMARKTPLATZ (2006) 
administrative law ${ }^{163}$ - had often made it out to be. As Saskia Sassen has recently reiterated, both dryly and unrefutingly, there is an intimate connection between both the search for and the critique of law and the nation state. ${ }^{164}$ Her observation is particularly astute as Sassen has, over the years ${ }^{165}$, much contributed to our better understanding of how allegedly 'external' and overwhelming processes of 'globalization' should instead be seen as distinctly co-evolving with and as being produced, constructed and conceived of within the nation state. Rather than positing globalization as a process, event or development that imprisons nation states, national economies and domestic political processes, Sassen prompts us to take a closer look at how the local is the dominant place of decision-making. Yet, she doesn't suggest a simple return to statism: instead, she suggests that there is a dynamic relation between locally identifiable processes of institutional and normative formation and the emergence of spatial regulatory regimes. It is through this relation that elements of physical and intellectual texture emerge to produce border-crossing 'global assemblages'. These constitute distinct spheres that, famously fuelled by the dramatic development of information technology, integrate territorial and de-territorial, vertical and horizontal ordering patterns to produce a structured regime of societal activities. ${ }^{166}$

${ }_{163}$ Carl Schmitt, Political Theology: Four Chapters on the concept of sovereignty [1922] (transl. George Schwab) (1986); Ernst Forsthoff, The Administration as Provider of Services (transl. from Der Staat der Daseinsvorsorge, 1938), in: WEIMAR. A JURISPRUDENCE IN CRISIS 326 (Jacobson/Schlink Ed. 2000)

164 Saskia Sassen, Territory - Ruthority - Tights. From Medieval to Global AsSemblages (2006), 1: “We are living through an epochal transformation, one as yet young but already showing its muscle. We have come to call this transformation globalization, and much attention has been paid to the emerging apparatus of global institutions and dynamics. Yet, if this transformation is indeed epochal, it has to engage the most complex institutional architecture we have ever produced: the national state."

165 See, for example, Saskia Sassen, The Mobility of LABor and CAPITAL. A Study IN InTERnATIONAL InVESTMEnT and LABor Flow (1988); SASKia SASSEn, The Global City (1991); SASKia SASSEn, GLOBalization AND ITS DisContents. ESSAYS ON THE NEW Mobility of PEOPLE AND Money (1998); Saskia Sassen, Globalization or denationalization?, 10 Review of InTERnational Political EConomy 1 (2003); Saskia Sassen, The City: Its Return as Lens for Social Theory. Keynote presentation at the International Conference for Integrating Urban Knowledge \& Practice, Gothenburg, Sweden, May 29 to June 5, 2005, http://www.urbanlife2005.com/proceedings/keynotes/Saskia_Sassen.pdf (2005)

166 SASkia SASSEn, TerRitory - Ruthority - Tights. From MedieVAl to Global AsSEmblages (2006) 
Meanwhile, continental public lawyers remain tempted to depict transnationalization processes primarily as challenges to the reassertion of 'public authority'167 in a world of disaggregated state power. ${ }^{168}$ Similarly, European private lawyers continue to coyly attempt an escape from the reach of the juridification/intervention thrust by demarcating 'traditionalists' from 'transnationalists' - in the hope of positing the latter as heroes of an autonomous legal order, distinct from the nation state. ${ }^{169}$ Such intellectual efforts occur side-by-side with continuing discussions and the untiring production of legislative proposals around a European private law. ${ }^{170}$ Both projects provide telling illustrations of how transnational economic and commercial activities continue to challenge a state-based model of interventionist law to adapt itself to a sphere structured by private self-regulation and political regulatory competition. ${ }^{171}$ What is remarkable is the lack of real dialogue between 'public' and 'private' lawyers in this regard. While the conceptual and political problems arising around emerging and proliferating regulatory regimes in the transnational sphere are obvious, public and private lawyers appear to pursue distinct and isolated paths, the former being interested in further scrutiny of 'sovereignty' and 'authority'172 and the latter re-directing their interests to longstanding questions of regulatory competition. ${ }^{173}$ There is a real opportunity here for public and private lawyers

\footnotetext{
167 See, for example, the Special Issue "The Exercise of Public Authority by International Organizations" (Armin von Bogdandy, Philip Dann \& Matthias Goldmann eds., GERMAN LAW JournAL, vol. 9, no. 11, 2008), available at http://www.germanlawjournal.com/index.php?pageID=13\&vol=9\&no=11

168 Anne-Marie Slaughter, Disaggregated Sovereignty: Towards the Public Accountability of Global Government Networks, 39 Government And Opposition 159 (2004); Anne-Marie Slaughter, A NeW World ORdER (2004)

169 Klaus Peter Berger, The Creeping Codification of the Lex Mercatoria (1999); Klaus Peter Berger, The New Law Merchant and the Global Market Place. A 21st Century View of Transnational Commercial Law, in: THE Practice of Transnational LaW 1 (Berger Ed. 2001); for a critical discussion, see Peer Zumbansen, Piercing the Legal Veil: Commercial Arbitration and Transnational Law, 8 EUROPEAN LAW JouRnAL 400 (2002)

170 For an excellent overview and analysis, see Reinhard Zimmermann, The Present State of European Private Law, 57 AMERICAN JOURNAL OF COMPARATIVE LAW 479 (2009).

171 Geraint Howells/Thomas Wilhelmsson, EC Consumer Law: Has it Come of Age?, 28 EuROPEAN LAW REVIEW 370 (2003); Ugo Mattei/Fernanda Nicola, A 'Social Dimension' in European Private Law? The Call for Setting a Progressive Agenda, 41 NEW ENGLAND LAW REVIEW 1 (2006)

172 See von Bogdandy et al, supra, note 167.

173 Erin A. O'Hara/Larry E. RibSTEIn, The LAW MARKet (2009); Horst Eidenmüller, Recht als Produkt, 64 JURISTENZEITUNG [JZ] 641 (2009)
} 
to join forces in order to unpack the intricate combination of state/non-state and public/private dimensions inherent to the emerging transnational regulatory landscape. ${ }^{174}$ The opportunity arises out of the rich theoretical and doctrinal memories of public and private law with regard to the thematization of exclusion and inclusion, participation and representation. ${ }^{175}$ But, the danger is that the current efforts of studying the particular dynamics of fast-evolving transnational regulatory regimes are carried out with little interest in the national pasts of legal regimes.

Against this background, Sassen's idea of global assemblages allows us to structure the sphere between the national and the inter-/transnational/global that has been plaguing legal imagination for some time now. ${ }^{176}$ Sassen's work reflects an unerring commitment to simultaneously emphasize and relativize the national in the emerging cartography of a globalized world. This emphasis on national, local decisions and institutions that give rise to globalization processes has gone a long way in allowing us to identify the concrete places at which policies are prepared, taken and implemented that later become identified as phenomena of globalization. ${ }^{177}$ This new understanding of the national basis of globalization proceeds in relation to the well-known institutions, reference points and established procedures such as states, parliaments, administrative agencies and, importantly, courts. Those have long structured the economic, political and legal order and that are now struggling to re-ascertain their previously held roles and positions of power but in a transnational context. ${ }^{178}$ This relativization of the local results in the discovery of a

\footnotetext{
174 Caruso, supra, note 88

175 Rudolf Wiethölter, Materialization and Proceduralization in Modern Law, in: DiLEMMAS OF LAW IN THE WELFARE STATE 221 (Teubner Ed. 1986)

176 Gunther Teubner (Ed.), Global LaW Without A State, 1997

${ }^{177}$ Her work on global cities is of particular relevance in this regard: here, Sassen, has been arguing for decades that global cities gain autonomy from their local environments both by adapting real-time collaborative and networking capacities with other cities and operative centres and by successfully demanding and implementing a facilitating, supportive infrastructure (electricity, broadband, digitisation, $24 / 7$ service, access and maintenance). For a concise restatement of her long-term, monographical work on global cities, see Saskia Sassen, The Global City, in: ReAdings in URban Theory 61 (Fainstein/Campbell Ed. 1999).

${ }^{178}$ See the Symposium "Beyond Dispute: International Judicial Institutions as Lawmakers", edited by Armin von Bogdandy and Ingo Venzke, 12 GERMAN LAW JournaL 979-1370 (2011), available at:

http://www.germanlawjournal.com/index.php?pageID=2\&vol=12\&no=5
} 
newly emerging spatial category: the focus on space promises to more adequately capture the exhaustion of concretely localised places of legal and political regulation from the perspective of the rise in importance of hybrid institutional structures and normative orders. This constellation presents tremendous challenges to both an analytical and prescriptive framework that was developed with reference to a more or less well defined regulatory framework. The central challenge of this move from place to space consists in developing an appropriate language with which to communicate over the institutional and normative challenges in a world that cannot effectively be governed through domestic and domestically minded rules. In the emerging spaces of global societal activity the specifically legal perspective, which informs our present inquiry is challenged by a multitude of contrasting investigations into the form, nature and quality of the global order. ${ }^{179}$ Beyond the obvious need of irony on the part of the lawyer in his/her quest to make sense of law in a globalizing world to accept the relativity of the legal perspective lies, of course, the need to understand the continuing proliferation of pluralist normative orders.

\section{F. OUTLOOK}

The study of transnational governance has produced important insights into the complex relations between the emergence of hybrid institutions and the ambivalent, hard/soft norms produced in that context. There can be no doubt that these analytical efforts will continue to be carried out through various collaborations and exchanges between legal scholars, sociologists, political scientists, anthropologists and geographers, to name just a few of the participating disciplines. The emergence of transnational regulatory theory, however, is not necessarily a straight-forward or smooth process. It is within each discipline that one has to identify points of departure towards a new perspective or theoretical construct. The advent of 'governance' as an overarching term to capture the shift from state-based, nationally defined regulation to

\footnotetext{
179 See the still excellent exposition of the interdisciplinary nature of globalization studies: DAVID Held/Anthony McGrew (ED.), The Global Transformations Reader. An Introduction to the Globalization DEBATE (2000), 2ND ED., 2003, Introduction.
} 
transnational processes of norm creation and institutionalization contributes to a further 'interdisciplinarization' of research, but it remains crucial to continue to unpack the meaning of this shift to governance within different disciplines themselves. This paper has offered a number of observations regarding the adaptation of legal scholarship and doctrine to the process of transnationalization, and at every corner we were able to see that while we may no longer just be merely 'shooting in the dark', it would clearly be too early to say 'we see the light'. 